Acta vet. scand. 1969, 10, 292-294.

Brief communication

\title{
CHORIO-RETINITIS IN PORCINE TOXOPLASMOSIS
}

Porcine toxoplasmosis generally occurs as a latent disease in adolescent and adult pigs, but now and then also manifests itself as a fatal congenital disease in piglets. It is known to occur in USA (Farrel et al. 1952), Germany (Becker 1954), Denmark (Momberg-Jørgensen 1956), Mexico (Varela et al. 1956), Japan (Sato et al. 1958), England (Harding et al. 1961) and Sweden (Hansen et al. to be published).

In addition to other signs, the clinical picture is characterized by various symptoms pertaining to the central nervous system as sequelae of focal necrosis, microabscesses and in more chronic cases, nonpurulent encephalitis with glial proliferations and perivascular lymphocytic cuffings.

In human congenital toxoplasmosis, Wolf et al. (1939) were the first to describe the so-called classical triad of toxoplasmosis manifested by chorio-retinitis, hydrocephalus and intracranial calcifications. This syndrome was reported to present the final stage of infection (Eichenwald 1948). Nevertheless, the frequency of ocular lesions in human congenital toxoplasmosis is so high that chorio-retinitis is very often the clue to diagnosis (Jacobs 1960). Feldman (1953) reported chorio-retinitis in $99 \%$ of neonatal cases studied by him while Eichenwald \& Levine (1954) reported that about $80 \%$ of cases showed such a symptom. Hogan (1951) was the first to give a description of chorio-retinitis of a typical segmental type.

In different species of domestic animals, chorio-retinitis and retinitis due to toxoplasmosis are presumably common but not invariably present. The lesion was reported in cat (Piper 1961, Vainisi \& Campbell 1969), cattle (Meyer 1963), dog (Barron \& Saunders 1959, Møller \& Nielsen 1964, Piper), pig (Varela et al.; Piper), poultry (Biering-Sørensen 1956) and in sheep (Piper). We therefore think it worth while to communicate briefly on an observation of chorio-retinitis as part of the toxoplasmosis syndrome in pigs. 

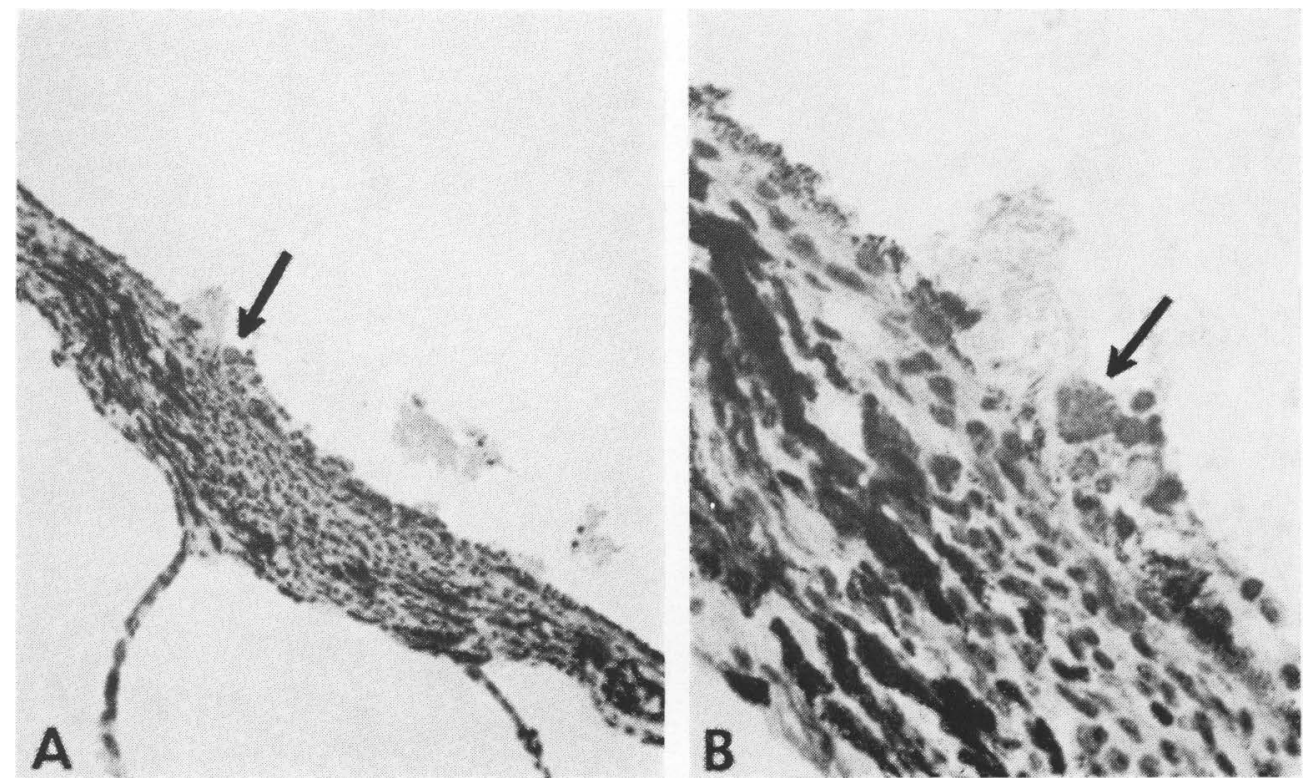

Fig u r e 1. O 7819/64. Toxoplasma chorio-retinitis in pig. A. Segmental swelling of the chorioid membrane, due to infiltration of lympho-histiocytic cells. Retina detached, except the pigment epithelium, where a toxoplasma pseudocyst is seen (arrow). H.-E. $150 \times$. B. Close up of same. H.-E. $500 \times$. 

In 1964, a whole litter of piglets in south-western Sweden fell ill a fortnight after a normal delivery from a clinically healthy gilt. Death was generally preceded by symptoms of general malaise, diarrhoea, coughing and dyspnoea, ataxia and other symptoms from the central nervous system. Typical lesions of toxoplasmosis were revealed patho-anatomically, and the diagnosis was confirmed according to the mouse inoculation test. Two piglets survived and were clinically observed for three months before being sacrificed; one of them showed a defective vision. Its postmortal picture was that of nonpurulent meningoencephalitis and segmental chorio-retinitis. The latter lesion was seen in one eye and was only observed as a small segmental swelling of the chorioid membrane. This was mainly due to an infiltration of lympho-histiocytic cells. The association of this lesion with toxoplasmosis was ascertained by the presence of a toxoplasma pseudocyst in the retinal pigment epithelium (Fig. 1). The major part of the retina was detached. Whether this was an intravital or postmortal detachment could not be established with certainty.

In conclusion, a case of segmental chorio-retinitis was noticed during an outbreak of congenital toxoplasmosis in piglets. The lesion, clinically apparent at the age of three months, was histopathologically confirmed.

Hans-Jörgen Hansen

National Veterinary Institute, Stockholm, Sweden.

I. Eldisougi Mostafa

Faculty of Veterinary Science, University of Khartoum, Sudan.

\section{REFERENCES}

Barron, C. N. \& L. Z. Saunders: Ein Fall von intraokulärer Toxoplasmose beim Hund. (A case of ocular toxoplasmosis in dog). Schweiz. Arch. Tierheilk. 1959, 101, 349-354.

Becker, W.: Toxoplasmose beim Hausschwein. (Toxpplasmosis in pig). Diss., Giessen 1954, 32 pp.

Biering-Sørensen, U.: Fjerkrætoxoplasmose. Om forekomsten af endemisk optrædende toxoplasmose (toxoplasmosis gallinarum) i danske hønsebesætninger. (Poultry toxoplasmosis. On the occurrence of endemic toxoplasmosis (toxoplasmosis gallinarum) in Danish chicken flocks). Nord. Vet.-Med. 1956, 8, 140-164.

Eichenwald, H.: Experimental toxoplasmosis; transmission of infection in utero and through milk of lactating female mice. Amer. J. Dis. Child. 1948, 76, 307-315. 
Eichenwald, H. \& S. Z. Levine: Toxoplasmosis. Postgrad. Med. 1954, $15,282-286$.

Farrel, R. L., F. L. Docton, D. M. Chamberlain \& C. R. Cole: Toxoplasmosis. 1. Toxoplasma isolated from swine. Amer. J. vet. Res. 1952, 13, 181-185.

Feldman, $H$. A.: Clinical manifestations and laboratory diagnosis of toxoplasmosis. Amer. J. trop. Med. Hyg. 1953, 2, 420-428.

Harding, J. D. J., J. K. A. Beverly, I. G. Shaw, B. L. Edwards \& G. H. Bennett: Toxoplasma in English pigs. Vet. Rec. 1961, 73, 3-6.

Hogan, M. J.: Ocular toxoplasmosis. Diss., New York 1951.

Jacobs, L.: Ocular toxoplasmosis: Laboratory contributions to diagnosis and chemotherapy. In Human Toxoplasmosis, ed. J. C. Siim. Munksgaard, Copenhagen 1960, 149-158.

Meyer, $H$. F.: Isolation of Toxoplasma gondii from the retina of cattle. Rev. Med. vet. (B. Aires) 1963, 44, 423-430.

Momberg-Jørgensen, $H$. C.: Toxoplasmose hos svinet. (Toxoplasmosis in swine). Nord. Vet.-Med. 1956, 8, 227-238.

Møller, T. \& S. W. Nielsen: Toxoplasmosis in distemper-susceptible carnivora. Path. Vet. 1964, $1,189-203$.

Piper, $R$. C.: The ocular pathology of canine, feline, porcine, ovine, and bovine toxoplasmosis. Diss. Abstr. 1961, 21, 3066-3067.

Sato, H., Y. Saheki, T. Muto, I. Oishi, S. Kobayashi, Y. Miyamoto \& Y. Ochi: Studies on toxoplasmosis in domestic animals. I. Isolation of Toxoplasma gondii from pigs and dogs. Jap. J. vet. Sci. 1958, 20, $213-221$.

Vainisi, S. J. \& L. H. Campbell: Ocular toxoplasmosis in cats. J. Amer. vet. med. Ass. 1969, 154, $141-152$.

Varela, G., E. Roch \& J. Torroella: Toxoplasmosis ocular. (Ocular toxoplasmosis). Rev. Inst. Salubr. Enferm. trop. (Méx.) 1956, 16: 2, 17-19.

Wolf, A., D. Cowen \& B. H. Paige: Toxoplasmic encephalomyelitis. A new case of granulomatous encephalomyelitis due to a protozoon. Amer. J. Path. 1939, 15, 657-694. 